Hiroyasu Iwasa - Toshio Itoh • Ryozo Nagai

Yusuke Nakamura • Toshihiro Tanaka

\title{
Twenty single nucleotide polymorphisms (SNPs) and their allelic frequencies in four genes that are responsible for familial long QT syndrome in the Japanese population
}

Received: December 25, 1999 / Accepted: December 27, 1999

\begin{abstract}
We report here 20 single nucleotide polymorphisms (SNPs), including 10 novel ones, and their allelic frequencies detected in four genes that are known to be responsible for familial long QT syndrome in the Japanese population; 7 polymorphisms are in the KCNQ1 gene, 6 in the $K C N H 2$ gene, 5 in the $S C N 5 A$ gene, and 2 in the $K C N E 1$ gene. These data will be of use for genetic association studies of acquired cardiac arrhythmias.
\end{abstract}

Key words Long QT syndrome · Single nucleotide polymorphism - Japanese population $\cdot$ Acquired arrhythmia . Proarrhythmia

\section{Introduction}

Long QT syndrome (LQTS), an arrhythmogenic disorder characterized by prolongation of the QT interval on electrocardiograms (ECGs), often causes syncope or cardiac sudden death as the result of a recurrent and lethal arrhythmia, such as ventricular tachycardia, torsades de pointes, and ventricular fibrillation. Five genes responsible for this syndrome (KCNQ1 (also known as KVLQT1), KCNH2 (also known as HERG), KCNE1, KCNE2, and SCN5A) have been identified until now (Curran et al. 1995; Wang et al. 1996a; Wang et al. 1996b; Splawski et al. 1997; Abbott et al. 1999). Previous studies have suggested that some mild LQTS mutations may cause drug-induced LQTS (Donger et al. 1997; Abbott et al. 1999), leading to the expectation

H. Iwasa $\cdot$ Y. Nakamura $\cdot$ T. Tanaka $(\bowtie)$

Laboratory of Molecular Medicine, Human Genome Center,

Institute of Medical Science, University of Tokyo, 4-6-1

Shirokanedai, Minato-ku, Tokyo 108-8639, Japan

Tel. +81-3-5449-5374; Fax +81-3-5449-5406

e-mail: toshitan@ims.u-tokyo.ac.jp

H. Iwasa $\cdot$ T. Itoh

Second Department of Internal Medicine, Gunma University School of Medicine, Gunma, Japan

R. Nagai

Department of Cardiovascular Medicine, Graduate School of

Medicine, University of Tokyo, Tokyo, Japan that polymorphisms of LQTS-related genes will potentially provide useful information on acquired cardiac arrhythmias. Until now, 17 SNPs in these genes have been reported (Abbott et al. 1999; Akimoto et al. 1998; Itoh et al. 1998a; Lai et al. 1994; Larsen et al. 1999; Tesson et al. 1996; Wang et al. 1995).

Here we report single nucleotide polymorphisms in genes responsible for familial long QT syndrome in the Japanese population, along with their allelic frequencies.

\section{Subjects and methods}

In the course of our screening of mutations in Japanese patients with long QT syndrome, we have identified 20 polymorphisms in both LQTS patients and normal individuals. The screening method was as described previously (Itoh et al. 1998a). In brief, genomic DNA was prepared from blood samples according to the standard protocols. All exons of each gene (KCNQ1, KCNH2, $S C N 5 A, K C N E 1$, and $K C N E 2)$ and their flanking intronic sequences were amplified by polymerase chain reaction (PCR) primers described previously (Itoh et al. 1998a; Itoh et al. 1998b; Wang et al. 1996a), and analyzed by singlestrand conformation polymorphism (SSCP) analysis. Fragments presenting an aberrant conformer were sequenced using ABI 377 sequencers.

To further investigate the allelic frequencies in a normal control population, hybridization of allele-specific oligonucleotides was performed in 50 or 100 normal independent individuals as described previously (Saiki et al. 1986). Oligonucleotides specific for both alleles were synthesized and used to discriminate the two alleles.

\section{Results and discussion}

In total, we have confirmed 20 SNPs $(7$ in the $K C N Q 1$ gene, 6 in the $K C N H 2$ gene, 5 in the SCN5A gene, and 2 in the $K C N E 1$ gene) and examined their allelic frequencies in 
Table 1. Polymorphism of LQTS genes in Japanese population

\begin{tabular}{|c|c|c|c|c|c|c|}
\hline Gene & Nucleotide change $^{\mathrm{a}}$ & $\begin{array}{l}\text { Amino acid } \\
\text { change }\end{array}$ & $\begin{array}{l}\text { Frequency of } \\
\text { minor allele }\end{array}$ & Region & $\begin{array}{l}\text { Number of chromosomes } \\
\text { examined }\end{array}$ & $\begin{array}{l}\text { Previous report } \\
\text { (if any) }\end{array}$ \\
\hline \multirow[t]{7}{*}{$K C N Q 1$} & $435 \mathrm{C}>\mathrm{T}$ & I145I & 0.06 & Exon 3 & 100 & \multirow[t]{3}{*}{ Itoh et al. 1998a } \\
\hline & $1110 \mathrm{G}>\mathrm{A}$ & A370A & 0.04 & Exon 10 & 100 & \\
\hline & $1394-12 \mathrm{C}>\mathrm{T}$ & Intronic variant & 0.04 & Intron 12 & 100 & \\
\hline & $1638 \mathrm{G}>\mathrm{A}$ & S546S & 0.28 & Exon 15 & 100 & \multirow{3}{*}{ Lee et al. 1997} \\
\hline & $1685+23 \mathrm{G}>A$ & Intronic variant & 0.04 & Intron 15 & 100 & \\
\hline & $1732+43 \mathrm{~T}>\mathrm{C}$ & Intronic variant & 0.23 & Intron 16 & 100 & \\
\hline & $1927 \mathrm{G}>\mathrm{A}$ & G643S & 0.09 & Exon 18 & 100 & Itoh et al. 1998a \\
\hline \multirow[t]{6}{*}{$\mathrm{KCNH} 2$} & $1467 \mathrm{~T}>\mathrm{C}$ & I489I & 0.33 & Exon 6 & 100 & Akimoto et al. 1998 \\
\hline & $1539 \mathrm{~T}>\mathrm{C}$ & F513F & 0.28 & Exon 6 & 100 & Akimoto et al. 1998 \\
\hline & $1692 \mathrm{~A}>\mathrm{G}$ & L564L & 0.06 & Exon 7 & 100 & Akimoto et al. 1998 \\
\hline & $1956 \mathrm{~T}>\mathrm{C}$ & Y652Y & 0.12 & Exon 8 & 98 & Larsen et al. 1999 \\
\hline & $2690 \mathrm{~A}>\mathrm{C}$ & K897T & 0.02 & Exon 11 & 100 & \\
\hline & $2965+22 A>G$ & Intronic variant & 0.22 & Intron 12 & 100 & \\
\hline \multirow[t]{5}{*}{$S C N 5 A$} & $1673 \mathrm{~A}>\mathrm{G}$ & H558R & 0.08 & Exon 12 & 100 & \\
\hline & $3269 \mathrm{C}>\mathrm{T}$ & P1090L & 0.04 & Exon 18 & 100 & \\
\hline & $4299+53 \mathrm{~T}>\mathrm{C}$ & Intronic variant & 0.27 & Intron 24 & 100 & \\
\hline & $5457 \mathrm{C}>\mathrm{T}$ & D1819D & 0.46 & Exon 28 & 100 & Wang et al. 1995 \\
\hline & $5851 \mathrm{G}>\mathrm{T}$ & V1951L & 0.005 & Exon 28 & 200 & \\
\hline \multirow{2}{*}{ KCNE1 } & $112 \mathrm{~A}>\mathrm{G}$ & S38G & 0.19 & Exon 1 & 98 & Lai et al. 1994 \\
\hline & $253 \mathrm{G}>\mathrm{A}$ & $\mathrm{D} 85 \mathrm{~N}$ & 0.02 & Exon 1 & 100 & Tesson et al. 1996 \\
\hline
\end{tabular}

${ }^{a}$ Nucleotide numbering starts from ATG start codon (GenBank accession numbers AF000571 [KCNQ1], U04270 [KCNH2], NM000335 [SCN5A], M26685 [KCNE1], and NM005136 [KCNE2])

Japanese population. We were unable to detect any polymorphism in the KCNE2 gene. Table 1 shows a summary of SNPs detected in our samples.

Among 17 SNPs reported previously, 7 could not be detected in this study. Although the sensitivity of the PCRSSCP analysis could be one of the reasons for this nondetection, there must be differences in SNP distribution and/or allelic frequencies among ethnic groups. As we could not obtain information on the allelic frequencies of the 10 other SNPs that overlapped with those in the previous studies, we could not directly compare our results in the Japanese population with those in Caucasian populations.

We believe these data will provide useful information for the identification of genes related to secondary arrhythmia, for the classification of patients at high risk of proarrhythmia, and, eventually, for the selection of antiarrhythmic agents with possible proarrhythmic effects for these patients.

Acknowledgments This work was supported in part by a Grant-in-Aid from the Ministry of Education, Science, Sports, and Culture of Japan.

\section{References}

Abbott GW, Sesti F, Splawski I, Buck ME, Lehmann MH, Timothy KW, Keating MT, Goldstein SA (1999) MiRP1 forms $I_{\mathrm{Kr}}$ potassium channels with HERG and is associated with cardiac arrhythmia. Cell 97:175-187

Akimoto K, Furutani M, Imamura S, Furutani Y, Kasanuki H, Takao A, Momma K, Matsuoka R (1998) Novel missense mutation (G601S) of HERG in a Japanese long QT syndrome family. Hum Mutat Suppl 1:S184-186

Curran ME, Splawski I, Timothy KW, Vincent GM, Green ED, Keating MT (1995) Molecular basis for cardiac arrhythmia: HERG mutations cause long QT syndrome. Cell 80:795-803

Donger C, Denjoy I, Berthet M, Neyroud N, Cruaud C, Bennaceur M, Chivoret G, Schwartz K, Coumel P, Guicheney P (1997) KVLQT1
C-terminal missense mutation causes a forme fruste long-QT syndrome. Circulation 96:2778-2781

Itoh T, Tanaka T, Nagai R, Kikuchi K, Ogawa S, Okada S, Yamagata S, Yano K, Yazaki Y, Nakamura Y (1998a) Genomic organization and mutational analysis of $K V L Q T 1$, a gene responsible for familial long QT syndrome. Hum Genet 103:290-294

Itoh T, Tanaka T, Nagai R, Kamiya T, Sawayama T, Nakayama T, Tomoike H, Sakurada H, Yazaki Y, Nakamura Y (1998b) Genomic organization and mutational analysis of $H E R G$, a gene responsible for familial long QT syndrome. Hum Genet 102:435-439

Lai LP, Deng CL, Moss AJ, Kass RS, Liang CS (1994) Polymorphism of the gene encoding a human minimal potassium ion channel (minK). Gene 151:339-340

Larsen LA, Christiansen M, Vuust J, Andersen PS (1999) Highthroughput single-strand conformation polymorphism analysis by automated capillary electrophoresis: robust multiplex analysis and pattern-based identification of allelic variants. Hum Mutat 13:318 327

Lee MP, Hu RJ, Johnson LA, Feinberg AP (1997) Human KVLQT1 gene shows tissue-specific imprinting and encompasses BeckwithWiedemann syndrome chromosomal rearrangements. Nat Genet 15:181-185

Saiki RK, Bugawan TL, Horn GT, Mullis KB, Erlich HA (1986) Analysis of enzymatically amplified beta-globin and HLA-DQ alpha DNA with allele-specific oligonucleotide probes. Nature 324:163166

Splawski I, Tristani-Firouzi M, Lehmann MH, Sanguinetti MC, Keating MT (1997) Mutations in the hminK gene cause long QT syndrome and suppress $\mathrm{I}_{\mathrm{Ks}}$ function. Nat Genet 17:338-340

Tesson F, Donger C, Denjoy I, Berthet M, Bennaceur M, Petit C, Coumel P, Schwarts K, Guicheney P (1996) Exclusion of KCNE1 $(I s K)$ as a candidate gene for Jervell and Lange-Nielsen syndrome. $\mathrm{J}$ Mol Cell Cardiol 28:2051-2055

Wang Q, Shen J, Splawski I, Atkinson D, Li Z, Robinson JL, Moss AJ, Towbin JA, Keating MT (1995) SCN5A mutations associated with an inherited cardiac arrhythmia, long QT syndrome. Cell 80:805-811

Wang Q, Li Z, Shen J, Keating MT (1996a) Genomic organization of the human $S C N 5 A$ gene encoding the cardiac sodium channel. Genomics 34:9-16

Wang Q, Curran ME, Splawski I, Burn TC, Millholland JM, VanRaay TJ, Shen J, Timothy KW, Vincent GM, de Jager T, Schwartz PJ, Towbin JA, Moss AJ, Atkinson DL, Landes GM, Connors TD, Keating MT (1996b) Positional cloning of a novel potassium channel gene: KVLQT1 mutations cause cardiac arrhythmias. Nat Genet $12: 17-23$ 